\title{
Bruk av skjema i oppfølgingen av diabetes i allmennpraksis
}

\begin{abstract}
BAKGRUNN De fleste pasienter med diabetes type 2 følges opp i allmennpraksis. Vi har undersøkt om allmennlegers bruk av skjemaer for registrering av kliniske data bidrar til lavere dødelighet og sykelighet for denne pasientgruppen.
\end{abstract}

MATERIALE OG METODE Denne systematiske oversikten bygger på søk i MEDLINE, EMBASE, ISI Web of Science, Cochrane CENTRAL og PubMed. Vi inkluderte studier som omhandlet voksne over 18 år med diabetes som ble fulgt opp i primærhelsetjenesten der man sammenlignet dødelighet og sykelighet med og uten bruk av skjema. Resultatene er oppsummert kvalitativt og i metaanalyser.

RESULTATER Vi inkluderte syv studier. I én studie (1 263 deltakere) unders $ø$ kte man effekten av skjemabruk på harde utfallsmål, uten at det ble funnet tydelige effekter på dødelighet (HR 0,91; $95 \% \mathrm{KI} 0,72-1,14$ ), hjerteinfarkt (OR 0,65; $95 \% \mathrm{KI} 0,31-1,35$ ), hjerneslag (OR 0,89; $95 \% \mathrm{KI} 0,39-2,01$ ), perifer nerveskade (OR 0,86; $95 \% \mathrm{KI} 0,57-1,29$ ) eller retinopati (OR 0,90; $95 \% \mathrm{KI} 0,53-1,52$ ). Bruk av skjema har trolig liten eller ingen effekt på kroppsvekt (tre studier), men en liten, positiv effekt på blodtrykk (fem studier) og totalkolesterolnivå (to studier).

FORTOLKNING Publiserte data gir foreløpig ikke klare svar, men det er en tendens til at bruk av skjema i oppfølgingen av pasienter med diabetes hos allmennlegen kan bidra til lavere dødelighet og sykelighet.

I 2014 var det rundt 220000 personer med kjent diabetes mellitus i Norge (1). Av disse hadde $80-90 \%$ diabetes type 2 . De aller fleste blir fulgt opp i primærhelsetjenesten (2). Norsk selskap for allmennmedisin (NSAM) utga fra 1988 til 2004 et handlingsprogram for diabetes i allmennpraksis (3). Dette arbeidet ble i 2009 videreført som nasjonale faglige retningslinjer fra Helsedirektoratet om forebygging, diagnostikk og behandling av sykdommen (4). I retningslinjene understrekes viktigheten av kostomlegging, røykeslutt og fysisk aktivitet og kontroll av blodsukkernivå, blodtrykk, blodlipider og vekt, og det anbefales regelmessige kontroller hver 2.-6. måned (4).

Bruk av papirbaserte eller elektroniske skjemaer for systematisk registrering av kliniske data kan bidra til bedre oppfølging av personer med kroniske lidelser (5). Skjemaer for bruk i diabetesoppfølgingen kan omfatte alt fra enkle papirskjemaer til mer avanserte løsninger der data bearbeides og det gis tilbakemeldinger tilpasset enkeltpasienter, for eksempel forslag til endringer $i$ behandling eller oppfølging.

Noen skjemaer brukes for å samle inn data til sentrale registre og kan for eksempel gi grunnlag for automatiserte tilbakemeldinger om hvorvidt pasientene som tilhører én lege eller én gruppepraksis oppnår behandlingsmålene sammenlignet med nasjonale eller regionale gjennomsnitt.

Det er utviklet et elektronisk skjema til bruk på fastlegekontoret for oppfølging av pasienter med diabetes (NOKLUS' diabetesskjema). Dette er ment å være både et klinisk verktøy for allmennlegen og et innsamlingsverktøy for Norsk diabetesregister (6).

Det foreligger flere systematiske oversikter om effekten av ulike tiltak i diabetesoppfølgingen, men ingen omhandler spesifikt bruken av skjemaer for registrering av kliniske data (7). Etter en henvendelse fra Norsk forening for allmennmedisin (NFA) har vi gjennomført en systematisk oversikt omkring mulige helsegevinster ved bruk av skjemaer i diabetesoppfølgingen hos allmennlegen.

\section{Materiale og metode}

Vi gjorde systematiske søk etter studier i databasene MEDLINE (Ovid), EMBASE (Ovid), ISI Web of Science, Cochrane CENTRAL og PubMed fra oppstart av databasene til juni 2015. I søket kombinerte vi tekst- og emneord som beskriver populasjonen og intervensjonen, for eksempel (diabet*) AND (structured care OR benchmarking OR decision support systems OR structured assessment OR standardized patient record).

Søket ble videre avgrenset med søkeord for relevante studiedesigner, og deler av det ble avgrenset med søkeord for primærhelsetjenesten (f.eks. primary care OR community care) (larunappendiks1). Vi lette også etter relevante studier ved å gjennomgå referanselister i inkluderte artikler.

\author{
Lillebeth Larun \\ lillebeth.larun@fhi.no \\ Kunnskapssenteret i Folkehelseinstituttet \\ og \\ Senter for kunnskapsbasert praksis \\ Høgskolen i Bergen \\ Trine Bjørner \\ Institutt for helse og samfunn \\ Universitetet i Oslo

\section{Atle Fretheim} \\ Kunnskapssenteret i Folkehelseinstituttet \\ og \\ Institutt for helse og samfunn \\ Universitetet i Oslo

\section{Kjetil G. Brurberg} \\ Kunnskapssenteret i Folkehelseinstituttet \\ og \\ Senter for kunnskapsbasert praksis \\ Høgskolen i Bergen
}

> Se lederartikkel side 376

Engelsk oversettelse på www.tidsskriftet.no

Appendiks på www.tidsskriftet.no/larun lappendiks og www.tidsskriftet.no/larunZappendiks

\section{HOVEDBUDSKAP}

Det foreligger ingen dokumentasjon på at bruk av skjema i diabetesoppfølgingen gir redusert risiko for død, hjerteinfarkt, hjerneslag, perifere nerveskader eller retinopati

Bruk av skjema har liten eller svært begrenset effekt på nivået av $\mathrm{HbA}_{1 \mathrm{c}}$, blodtrykk, vekt, lipider og mikroalbuminuri 
RAMME 1

Kriterier for utvelgelsen av studier

Studiedesign

Randomiserte, kontrollerte studier

Pasient

Voksne > 18 år med diabetes som følges opp i primærhelsetjenesten

Intervensjon

Bruk av diabetesskjema med eller uten tilpasset tilbakemelding

\section{Kontroll}

Oppfølging uten bruk av diabetesskjema, for eksempel ordinær bruk av elektronisk pasientjournal

\section{Utfall}

Primære: Dødelighet, koronar sykdom, hjerneslag og komplikasjoner som nyresvikt, perifer nevropati eller retinopati

Sekundære: Langtidsblodsukker $\left(\mathrm{HbA}_{1 \mathrm{c}}\right)$, blodtrykk, vekt, lipider eller mikroalbuminuri

Eksklusjon: Studier der man bare rapporterer måloppnåelse, det vil si andelen som følges opp i tråd med gjeldende retningslinje

\section{Oppfølgingstid}

Mer enn 12 måneder etter at skjemaet ble fylt ut for første gang

Søket resulterte i 2940 titler og sammendrag, som vi vurderte opp mot forhåndsdefinerte seleksjonskriterier (ramme 1). Vi inkluderte $i$ alt syv randomiserte, kontrollerte studier (fig 1). Én av forfatterne (LL) ekstraherte data fra studiene og en annen (KGB) kontrollerte at innhentede data var korrekte. De samme to (LL og KGB) gjennomgikk alle inkluderte studier og vurderte risiko for skjevheter knyttet til pasientseleksjon, utførelse, påvisning, oppfølging og rapportering (8). I vurderingen av dette er randomiseringsprosedyre, maskering av deltakere, maskering av personell og frafallsanalyser viktig.

Når randomisering foretas på klyngenivå, for eksempel ved at det er et legekontor heller enn enkeltpasienter som randomiseres, må man ta høyde for dette $\mathrm{i}$ beregningen av konfidensintervaller og p-verdier. Våre analyser er derfor basert på resultater med justering for klyngeeffekter. Der det har vært mulig, har vi også benyttet effektestimater som er justert for eventuelle forskjeller mellom gruppene ved studieoppstart.

Vi rapporterer dikotome utfallsmål som hasardratio (HR), som er et effektmål for tid

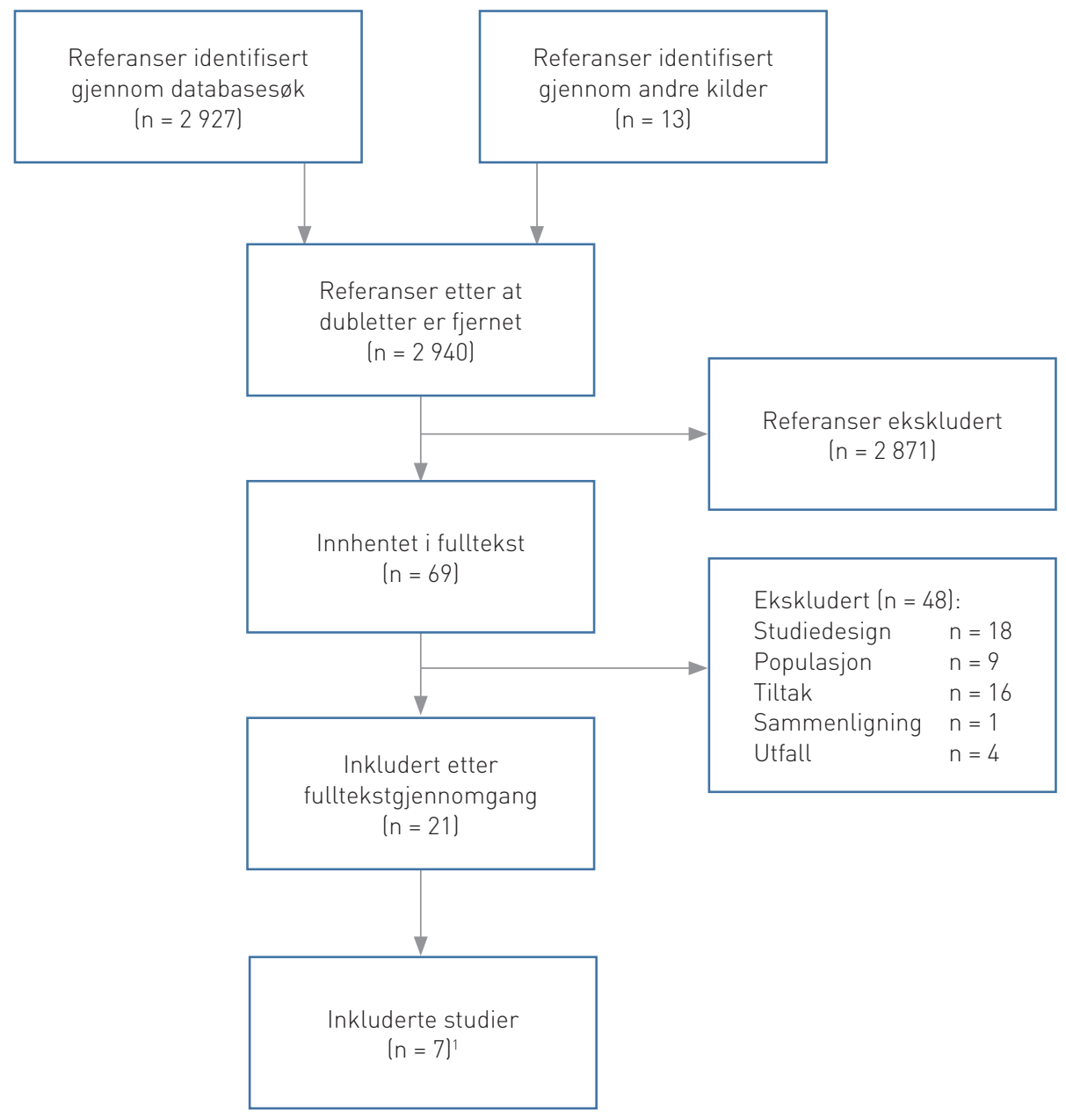

Figur 1 Utvelgelsesprosessen

til hendelse, eller oddsratio (OR), som er et effektmål for odds for en hendelse på et bestemt tidspunkt. Kontinuerlige utfall rapporterer vi som gjennomsnittsforskjeller (MD). Metaanalyser er utført i Review Manager Software (RevMan) (9) ved bruk av en random effektmodell som tar hensyn til at den sanne effekten kan variere mellom enkeltstudier. Hovedvekten var lagt på harde utfall, som risiko for død, koronar sykdom og hjerneslag. Vi sammenstilte resultater for primær- og sekundærutfall (ramme 1).

Kvaliteten på dokumentasjonen ble vurdert med GRADE-skalaen (Grading of Recommendations Assessment, Development and Evaluation) (10). Denne artikkelen blir publisert samtidig med en rapport fra Kunnskapssenteret i Folkehelseinstituttet (11). Prosjektplanen for dette arbeidet ble publisert i november 2014 (12).

\section{Resultater}

Vi inkluderte syv randomiserte, kontrollerte studier publisert mellom 2001 og 2011 (tab 1) (13-19). Tre studier var utført i USA (13-15), én i Nederland (16), én i Storbritan- nia (17), én i Canada (18) og én i Danmark (19). Antall pasienter varierte fra 335 til 7412 , og gjennomsnittsalderen var rundt 60 år. Gode randomiseringsprosedyrer med skjult fordeling av deltagerne er beskrevet $\mathrm{i}$ tre av studiene, og vi vurderer at disse studiene har lav risiko for skjevhet $(13,18,19)$. Det ble vurdert at de resterende studiene hadde høy risiko for skjevhet, først og fremst fordi randomiserings- og maskeringsprosedyrer var uklart beskrevet (8).

I alle studiene hadde legene brukt diabetesskjema, i to av dem i samarbeid med sykepleier $(16,17)$. Tid brukt på opplæring lå på rundt én time der dette ble rapportert. Skjemaet var integrert i den elektroniske pasientjournalen i de fleste studiene (tab 1). Mulighetene for bearbeiding av registrerte pasientdata varierte. Dette kunne være funksjoner som automatiske påminnelser til pasienten (18), påminnelser om innkalling til time $(13,16,18)$, forslag om endringer i medisinering $(14,18,20)$ og tilbakemelding om registrerte data for pasienten eller legepraksisen sammenliknet med andre (13, 14, 19). 
Tabell 1 Beskrivelse av de inkluderte randomiserte, kontrollerte studiene $(n=7)$

\begin{tabular}{|c|c|c|c|c|c|}
\hline $\begin{array}{l}\text { Førsteforfatter, år, } \\
\text { land (referanse) }\end{array}$ & $\begin{array}{c}\text { Antall } \\
\text { deltakere }\end{array}$ & $\begin{array}{l}\text { Interven- } \\
\text { sjonens } \\
\text { varighet }\end{array}$ & $\begin{array}{l}\text { Var skjemaet } \\
\text { integrert } \\
\text { i elektronisk } \\
\text { pasient- } \\
\text { journal? }\end{array}$ & $\begin{array}{l}\text { Hvilke pasientdata } \\
\text { ble registrert? }\end{array}$ & Hvilke tilbakemeldinger fikk behandlende lege? \\
\hline $\begin{array}{l}\text { Bebb, 2007, } \\
\text { Storbritannia (17) }\end{array}$ & 1534 & $1 \mathrm{år}$ & Uklart & Blodtrykk & Ikke oppgitt \\
\hline $\begin{array}{l}\text { Cleveringa, 2008, } \\
\text { Nederland (16) }\end{array}$ & 3391 & 1 år & Ja & $\begin{array}{l}\mathrm{HbA}_{1 c} \text {, blodtrykk, lipider, } \\
\text { vekt, røyking }\end{array}$ & $\begin{array}{l}\text { Automatisk innkalling til kontroller } \\
\text { Tilbakemelding om pasienten når behandlingsmål }\end{array}$ \\
\hline $\begin{array}{l}\text { Holbrook, } 2009, \\
\text { Canada (18) }\end{array}$ & 511 & $6 \mathrm{md}$ & Ja & $\begin{array}{l}\mathrm{HbA}_{1 c}, \text { blodtrykk, lipider, } \\
\text { albuminuri, vekt, røyking }\end{array}$ & $\begin{array}{l}\text { Månedlig automatisk telefonpåminnelse til pasienten } \\
\text { om medisinering, bestilling av legetime og prøvetaking }\end{array}$ \\
\hline $\begin{array}{l}\text { MacLean, } 2004, \\
\text { USA (13) }\end{array}$ & 7412 & 3 år & Ja & $\begin{array}{l}\mathrm{HbA}_{1 c}, \text { blodtrykk, lipider, } \\
\text { vekt }\end{array}$ & $\begin{array}{l}\text { Påminnelse hvis laboratorieprøver er over terskel } \\
\text { og oppfølgingstime ikke avtalt } \\
\text { Legen mottar tilbakemelding om status for sine } \\
\text { pasienter i forhold til studiepopulasjonen }\end{array}$ \\
\hline $\begin{array}{l}\text { O'Connor, 2009, } \\
\text { USA (14) }\end{array}$ & $3703^{1}$ & 3 år & $\mathrm{Ja}^{2}$ & $\mathrm{HbA}_{1 c}$, blodtrykk, lipider & $\begin{array}{l}\text { Data med relevans for diabetesbehandlingen tilsendt } \\
\text { hver } 4 \text {. måned } \\
\text { Foreslår endring i medisinering, testing og konsulta- } \\
\text { sjonsfrekvens } \\
\text { Legen mottar tilbakemelding om status for sine } \\
\text { pasienter i forhold til studiepopulasjonen }\end{array}$ \\
\hline $\begin{array}{l}\text { O'Connor, 2011, } \\
\text { USA (15) }\end{array}$ & 2556 & $8 \mathrm{md}$ & $\mathrm{Ja}^{2}$ & $\mathrm{HbA}_{1 \mathrm{c}}$, blodtrykk, lipider & $\begin{array}{l}\text { Utfylt skjema øverst på journal som går inn til legen } \\
\text { Foreslår endring i medisinering, testing og konsulta- } \\
\text { sjonsfrekvens }\end{array}$ \\
\hline $\begin{array}{l}\text { Olivarius, 2001, } \\
\text { Danmark (19) }\end{array}$ & 1263 & 6 år & Nei & $\begin{array}{l}\mathrm{HbA}_{1 c}, \text { blodtrykk, lipider, } \\
\text { mikroalbuminuri, vekt }\end{array}$ & $\begin{array}{l}\text { Spørreskjema tilsendt en måned før konsultasjon } \\
\text { Årlig tilbakemelding om enkeltpasienters risikofaktorer, } \\
\text { medisinering, komplikasjoner og behandlingsmål } \\
\text { Oppfordret til å sette måltall }\end{array}$ \\
\hline
\end{tabular}

${ }^{1}$ Fordelt på én kontrollgruppe og tre ulike intervensjonsarmer

2 Indirekte: må trykke inne i journalen for å åpne ekstra modul

\section{Primærutfall}

I kun én studie (19) ble det rapportert resultater på våre primærutfall (ramme 1). Denne danske studien hadde 1263 deltagere. Resultatene viste ingen tydelig effekt av bruk av skjema på dødeligheten (HR 0,91; $95 \% \mathrm{KI}$ $0,72-1,14)$. For de andre utfallene varierte den estimerte effekten fra en oddsratio på $0,65(95 \%$ KI $0,31-1,35)$ for ikke-dødelige hjerteinfarkt til en oddsratio på $0,90(95 \% \mathrm{KI}$ $0,53-1,52$ ) for retinopati.

For alle de undersøkte utfallene var det positive tendenser i favør av skjemabruk, men effektestimatene var for upresise til at man kan konkludere sikkert. Vi vurderte kvaliteten på dokumentasjonen for disse utfallene gjennomgående som lav, fordi det kun lå én studie til grunn og på grunn av brede konfidensintervaller rundt effektestimatene ( $\operatorname{tab} 2$ ). Ikke i noen studier var det rapportert resultater for nyresvikt.

\section{Sekundærutfall}

I alle de inkluderte studiene ble effekten av bruk av skjema for minst ett sekundærutfall rapportert (ramme 1), og det var mulig å gjennomføre metaanalyser for flere av disse (larunappendiks2). Bruk av skjema hadde liten eller ingen effekt på kroppsvekt. Vi så derimot en viss effekt på totalkolesterolnivå og blodtrykk (fig 2). For eksempel fant vi en gjennomsnittlig endring i systolisk blodtrykk på $-2,99$ mm Hg (95 \% KI -4,38 til -2,59), basert på resultater fra fem studier (fig 2).

For langtidsblodsukkernivå og mikroalbuminurinivået var resultatene mer usikre. Kvaliteten på dokumentasjonen varierte mellom høy og lav for ulike utfall. Lav tillit til effektestimatene skyldes stort sett inkonsistente og/eller upresise resultater (brede konfidensintervaller) (tab 3).

\section{Diskusjon}

I denne systematiske gjennomgangen av forskningslitteraturen identifiserte vi kun én studie om sammenhengen mellom bruk av diabetesskjema der virkninger på harde utfallsmål som død og koronarsykdom var registrert (19). Resultatene pekte i positiv retning, men dokumentasjonen er foreløpig ikke tilstrekkelig til å bekrefte eller avkrefte en mulig effekt.

Vi identifiserte ytterligere seks studier om effekten av diabetesskjema på sekundærutfall som blodtrykks- og kolesterolnivå $(13-18)$. Vi fant at skjemabruk trolig fører til lavere nivåer hos pasientene, men størrelsen på effekten er liten. Bruk av skjema har trolig liten eller ingen effekt på pasientenes kroppsvekt, og virkningen på langtidsblodsukkernivå og mikroalbuminnivået urin er usikker. Det at vi fant få studier er i seg selv interessant og understreker at vi mangler data for å konkludere sikkert om hvorvidt bruk av strukturerte skjemaer er et kostnadseffektivt tiltak. Til denne kategorien hører også NOKLUS-skjemaet (6).

Tiltak for kvalitetsforbedring av klinisk praksis har gjennomgående liten til moderat effekt på tvers av tiltak og kliniske områder (21). Systematiske oversikter som ikke er avgrenset til diabetespasienter, har vist at databaserte systemer for klinisk beslutningsstøtte kan bidra til praksisendringer hos helsepersonell og mulig helsegevinst for pasientene $(22,23)$.

Tricco og medarbeidere oppsummerte funn fra 142 randomiserte studier av forskjellige tiltak for bedre oppfølging av personer med diabetes, men rapporterte ikke spesifikt på effekten av diabetesskjemaer (24). De fant tydelige effekter på prosessmål som forskrivning av acetylsalisylsyre og blodtrykkssenkende medikamenter, men mindre 
Tabell 2 GRADE-tabell for dødelighet, hjerte- og karsykdom, retinopati og perifer nevropati

\begin{tabular}{|c|c|c|c|c|c|}
\hline \multirow[b]{2}{*}{ Utfall } & \multicolumn{2}{|c|}{ Beregnet absolutt effekt (95\% KI) } & \multirow[b]{2}{*}{$\begin{array}{c}\text { Relativ effekt } \\
\left(\mathrm{HR}^{1} / \mathrm{OR}^{2}\right)(95 \% \mathrm{KI})\end{array}$} & \multirow[b]{2}{*}{$\begin{array}{l}\text { Antall deltagere } \\
\text { (antall studier) }\end{array}$} & \multirow[b]{2}{*}{$\begin{array}{l}\text { Kvaliteten på doku- } \\
\text { mentasjonen (GRADE) }\end{array}$} \\
\hline & $\begin{array}{l}\text { Risiko med vanlig } \\
\text { oppfølging }\end{array}$ & $\begin{array}{c}\text { Risiko med strukturert } \\
\text { oppfølging }\end{array}$ & & & \\
\hline Dødelighet, per 1000 & 339 & $\begin{array}{c}314 \\
(258-377)\end{array}$ & $\begin{array}{c}\text { HR } 0,91 \\
(0,72-1,14)\end{array}$ & $1262(1)$ & $\begin{array}{l}\oplus \oplus \bigcirc \bigcirc \\
\operatorname{Lav}^{3,4}\end{array}$ \\
\hline Angina pectoris, per 1000 & 67 & $\begin{array}{c}61 \\
(34-107)\end{array}$ & $\begin{array}{c}\text { OR } 0,90 \\
(0,49-1,66)\end{array}$ & $714(1)$ & $\begin{array}{l}\oplus \oplus \bigcirc \bigcirc \\
\operatorname{Lav}^{3,4}\end{array}$ \\
\hline $\begin{array}{l}\text { Hjerteinfarkt (ikke-dødelige), } \\
\text { per } 1000\end{array}$ & 46 & $\begin{array}{c}30 \\
(15-61)\end{array}$ & $\begin{array}{c}\text { OR } 0,65 \\
(0,31-1,35)\end{array}$ & $830(1)$ & $\begin{array}{l}\oplus \oplus \bigcirc \bigcirc \\
\operatorname{Lav}^{3,4}\end{array}$ \\
\hline Slag (ikke-dødelige), per 1000 & 40 & $\begin{array}{c}35 \\
(16-76)\end{array}$ & $\begin{array}{c}\text { OR } 0,89 \\
(0,39-2,01)\end{array}$ & $851(1)$ & $\begin{array}{l}\oplus \oplus \bigcirc \bigcirc \\
\mathrm{Lav}^{3,4}\end{array}$ \\
\hline $\begin{array}{l}\text { Nyoppdaget perifer nevropati, } \\
\text { per } 1000\end{array}$ & 210 & $\begin{array}{c}186 \\
(131-255)\end{array}$ & $\begin{array}{c}\text { OR } 0,86 \\
(0,57-1,29)\end{array}$ & $704(1)$ & $\begin{array}{l}\oplus \oplus \bigcirc \bigcirc \\
\text { Lav }^{3.4}\end{array}$ \\
\hline Nyoppdaget retinopati, per 1000 & 136 & $\begin{array}{c}124 \\
(77-194)\end{array}$ & $\begin{array}{c}\text { OR } 0,90 \\
(0,53-1,52)\end{array}$ & $679(1)$ & $\begin{array}{l}\oplus \oplus \bigcirc \bigcirc \\
\operatorname{Lav}^{3,4}\end{array}$ \\
\hline
\end{tabular}

${ }^{1}$ HR: hasardratio

2 OR: oddsratio

${ }^{3}$ Basert på én studie med begrenset antall hendelser

${ }^{4}$ Svært upresist estimat (bredt konfidensintervall)

overbevisende resultater for mål på kliniske utfall, som blodtrykks- eller kolesterolnivå. De rapporterte ingen harde kliniske endepunkter. I lys av resultatene fra andre systematiske oversikter var det omtrent som forventet at vi fant usikre og små effekter av å benytte ulike typer diabetesskjema i klinisk praksis (24).

Formålet med studien var å undersøke om bruk av skjema i diabetesoppfølgingen gir redusert risiko for alvorlige komplikasjoner hos pasientene. Vi valgte å oppsummere studier der man hadde undersøkt denne sam- menhengen direkte, uten at det betyr at vår oppsummering gir en fullstendig oversikt over alle studier som er relevante for å vurdere fordeler og ulemper ved bruk av skjema. Til tross for omfattende søk i fem sentrale medisinske databaser kan vi ikke utelukke at vi har gått glipp av relevante studier.

Vi må også anerkjenne at det finnes studier som ikke tilfredsstilte våre inklusjonskriterier, men som kan ha relevans. Vi valgte for eksempel å ekskludere studier der man rapporterte om hvorvidt bruk av skjema fremmet etterlevelsen av behandlingsretningslinjer. Vi søkte heller ikke etter studier med kvalitativ design, som kunne ha gitt svar på hvordan bruk av skjema påvirker konsultasjonene eller hvordan pasienter og allmennleger opplever det.

I tillegg til avgrensninger i problemstilling og metode har også de inkluderte studiene begrensninger. Det var betydelig variasjon i måten tiltakene ble gjennomført på, hvordan skjemaene var utformet, hvilke tilbakemeldinger som ble gitt og om skjemaet var integrert i en elektronisk pasient-

\section{Systolisk blodtrykk (mm Hg)}

\begin{tabular}{|c|c|c|c|}
\hline $\begin{array}{l}\text { Førsteforfatter } \\
\text { (referanse) }\end{array}$ & Oppfølging & Antall & $\begin{array}{c}\text { Gjennomsnittsforskjell } \\
(95 \% \mathrm{KI})\end{array}$ \\
\hline Holbrooke (18) & $1 / 2 a ̊ r$ & 253 & $-3,95(-7,54--0,26)$ \\
\hline Bebb (17) & $1 \mathrm{arr}$ & 743 & $-1,30(-4,43-1,83)$ \\
\hline Cleveringa (16) & $1 \mathrm{ar}$ & 1699 & $-3,27(-6,02--0,52)$ \\
\hline MacLean (13) & $3 a ̊ r$ & 3886 & $-1,70(-4,00-0,80)$ \\
\hline Olivarius (19) & $6 a ̊ r$ & 455 & $-5,00(-7,60--2,40)$ \\
\hline
\end{tabular}

Total

$-2,99(-4,38--2,59)$

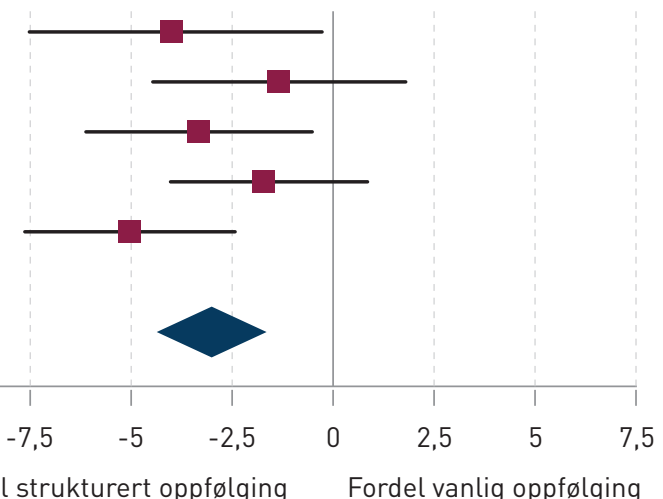

Figur 2 Balansediagram som viser effekten av strukturert oppfølging på systolisk blodtrykk. Fem studier trekker alle i samme positive retning (p < 0,0001), men den samlede effekten er liten $(-2,99 ; 95 \% \mathrm{Kl}-4,38--1,59) \mathrm{mm} \mathrm{Hg}$ 
Tabell 3 GRADE-tabell for $\mathrm{HbA}_{1 c}$, blodtrykk, vekt, lipider og mikroalbuminuri

\begin{tabular}{|c|c|c|c|c|}
\hline \multirow[b]{2}{*}{ Utfall } & \multicolumn{2}{|c|}{ Beregnet absolutt effekt (95\% KI) } & \multirow[b]{2}{*}{$\begin{array}{l}\text { Antall deltagere } \\
\text { (antall studier) }\end{array}$} & \multirow[b]{2}{*}{$\begin{array}{l}\text { Kvaliteten på doku- } \\
\text { mentasjonen (GRADE) }\end{array}$} \\
\hline & $\begin{array}{c}\text { Gjennomsnitt } \\
\text { ved vanlig oppfølging }\end{array}$ & $\begin{array}{l}\text { Gjennomsnittlig effekt } \\
\text { av strukturert oppfølging }\end{array}$ & & \\
\hline $\mathrm{HbA}_{1 \mathrm{c}}[\%]$ & $6,9-7,3$ & $\begin{array}{c}-0,05 \\
(-0,20 ; 0,09)\end{array}$ & $11314(3)^{1}$ & $\begin{array}{l}\oplus \oplus \bigcirc \bigcirc \\
\operatorname{Lav}^{2,3}\end{array}$ \\
\hline Systolisk blodtrykk [mm Hg] & $135-147$ & $\begin{array}{c}-\mathbf{2 , 9 9} \\
(-4,38 ;-1,59)\end{array}$ & $13598(5)$ & $\begin{array}{l}\oplus \oplus \oplus \bigcirc \\
\text { Middels² }\end{array}$ \\
\hline Diastolisk blodtrykk [mm Hg] & $75-82$ & $\begin{array}{c}-0,98 \\
(-1,97 ; 0,02)\end{array}$ & $13598(5)$ & $\begin{array}{l}\oplus \oplus \oplus \bigcirc \\
\text { Middels }^{2}\end{array}$ \\
\hline Koppsmasseindeks [kg/m²] & $31,9-33,7$ & $\begin{array}{l}-\mathbf{0 , 0 9} \\
(-0,47 ; 0,29)\end{array}$ & $7923(2)^{4}$ & $\begin{array}{l}\oplus \oplus \oplus \oplus \\
\mathrm{Høy}\end{array}$ \\
\hline Totalkolesterol [mmol/l] & $4,8-4,9$ & $\begin{array}{c}-\mathbf{0 , 1 8} \\
(-0,26 ;-0,10)\end{array}$ & $4248(2)$ & $\begin{array}{l}\oplus \oplus \oplus \bigcirc \\
\text { Middels }^{2}\end{array}$ \\
\hline HDL-kolesterol [mmol/l] & 1,33 & $\begin{array}{c}\mathbf{0 , 0 1} \\
(-0,01 ; 0,04)\end{array}$ & $3391(1)$ & $\begin{array}{l}\oplus \oplus \bigcirc \bigcirc \\
\mathrm{Lav}^{2,5}\end{array}$ \\
\hline LDL-kolesterol [mmol/l] & $2,4-2,6$ & $\begin{array}{c}-0,05 \\
(-0,16 ; 0,06)\end{array}$ & 11314 (3) & $\begin{array}{l}\oplus \oplus \bigcirc \bigcirc \\
\operatorname{Lav}^{2,3}\end{array}$ \\
\hline Albumin-kreatinin-ratio $[\mathrm{mg} / \mathrm{mmol}]$ & 5,95 & $\begin{array}{c}\mathbf{0 , 6 5} \\
(-1,11 ; 2,41)\end{array}$ & $272(1)^{6}$ & $\begin{array}{l}\oplus \oplus \bigcirc \bigcirc \\
\mathrm{Lav}^{5}\end{array}$ \\
\hline \multicolumn{5}{|c|}{$\begin{array}{l}1 \text { I tillegg viser studien til Olivarius og medarbeidere }(n=858) \text { en statistisk signifikant reduksjon i HbA } \mathrm{A}_{1 c} \text { på ca. } 0,9 \text { prosentpoeng }(95 \% \mathrm{KI} 0,83-0,93)(19) \\
{ }^{2} \text { Risiko for skjevheter grunnet metodiske begrensninger i én eller flere studier. } \\
{ }^{3} \text { Inkonsistente resultater på tvers av tilgjengelige studier } \\
{ }^{4} \text { I tillegg viser studien til Olivarius og medarbeidere }(n=852) \text { liten eller ingen vektendring: }-0,83 \mathrm{~kg}(-1,75 ; 0,09) \\
{ }^{5} \text { Svært upresise estimater }\end{array}$} \\
\hline
\end{tabular}

journal. Måten kontrollgruppen ble fulgt opp på, varierte også. Ideelt sett skulle vi ha utført sensitivitets- og subgruppeanalyser for å utforske forskjeller mellom de ulike variablene, men datamaterialet er for lite til at slike analyser er meningsfulle. En annen utfordring er at oppfølgingstiden i de fleste av studiene var begrenset til rundt ett år. Vi skulle gjerne ha sett flere studier med lengre oppfølgingstid.

Studiene i vår systematiske oversikt ble utført i vestlige land, med pasienter og helsesystemer som kan sies å ligne det norske kanskje med unntak av USA. Én utfordring er, som tidligere beskrevet, at det er brukt ulike typer skjema og ulike typer tilbakemelding. Likevel er vår overordnede vurdering at den tilgjengelige forskningslitteraturen gir kunnskap som belyser mulige virkninger av økt bruk av diabetesskjema i norsk allmennpraksis.

Det er flere hensyn å ta når nytten av et diabetesskjema skal vurderes. Diabetesskjemaet fra NOKLUS er ment både som klinisk verktøy for allmennlegen og som innsamlingsverktøy for Norsk diabetesregister. Det er lett å se verdien av et nasjonalt register som datagrunnlag for forskning som kan komme pasientene til gode.
For legers bruk av strukturerte skjemaer i pasientkonsultasjonene gjelder også hensynet til at konsultasjonen har tilmålt tid og at spørsmål fra pasienten krever oppmerksomhet. Det er viktig å kunne samtale med pasienten om følelsesmessige og praktiske forhold knyttet til det å leve med en kronisk sykdom. Rådgivning med tanke på livsstil er både tidkrevende og nødvendig. Tiden leger bruker på skjemautfylling, kan komme i konflikt med den samlede tiden som er til rådighet for direkte kontakt med pasienten.

Takstbruk for årskontroll av diabetes kan anskueliggjøre omfanget av bruken av NOKLUS-skjemaet i allmennpraksis. Bruken av taksten har ifølge HELFO økt fra totalt 12500 i 2012 til 17800 i 2014. Dette tilsvarer at hver fastlege kun benytter taksten omtrent tre ganger $\mathrm{i}$ året $(\mathrm{T}$. Nydal $\mathrm{i}$ HELFO, personlig meddelelse), det tilsvarer årskontroller for bare $10 \%$ av pasientene med diabetes type 2 .

Selv om de absolutte verdier for effekt på enkeltmålinger er små og neppe av stor klinisk betydning, kan disse små effektene likevel være med på å identifisere diabetespasienter med antatt dårlig kontroll. For disse pasientene er det en kjent økt sykelighet og dødelighet. Det er et selvstendig mål i praksis å redusere andelen pasienter med stor samlet risiko. Identifisering av dårlig kontrollerte pasienter er også viktig når leger skal bruke data for å sammenligne sin egen praksis med kollegers.

Økt bruk av NOKLUS-skjemaet er en uttrykt anbefaling fra Helsedirektoratet (25). Vår systematiske oversikt viser at den kliniske effekten av å bruke skjemaet er usikker. Det har vært registrert en bedring i diabetesoppfølgingen gjennom flere år, også før NOKLUS-skjemaet ble tatt i bruk (2). Det kan stilles spørsmål ved om skjemaet tilfredsstiller kriteriene for et godt og kostnadseffektivt tiltak, og det gjenstår fortsatt å se om økt bruk av strukturerte skjemaer er riktig medisin for ytterligere forbedring.

Man bør overveie å vurdere nytten av NOKLUS-skjemaet og måle virkning på dødelighet og sykelighet, hvordan allmennleger og pasienter opplever bruken av skjemaet og hvorvidt bearbeiding av innsamlede registerdata kan bedre kvaliteten på allmennlegenes oppfølging av denne pasientgruppen.

Vi takker Ola Morten Rygh og Ingvild Kirkehei, som har bidratt med søk, innsamling av data og kvalitetssikring. Takk også til Gro Jamtvedt, Liv Merete Reinar og fagfeller for innspill. 
Arbeidstid medgått er finansiert av Kunnskapssenteret i Folkehelseinstituttet.

\section{Lillebeth Larun (f. 1960)}

er seniorforsker og førsteamanuensis.

Forfatter har fylt ut ICMJE-skjemaet og oppgir ingen interessekonflikter.

\section{Trine Bjørner (f. 1953)}

er dr.med., spesialist i allmennmedisin, fastlege ved Majorstuhuset legegruppe og førsteamanuensis.

Forfatter har fylt ut ICMJE-skjemaet og oppgir ingen interessekonflikter.

\section{Atle Fretheim (f. 1968)}

er dr.med., seksjonsleder og førsteamanuensis.

Forfatter har fylt ut ICMJE-skjemaet og oppgir ingen interessekonflikter.

\section{Kjetil G. Brurberg (f. 1977)}

er seniorforsker og førsteamanuensis.

Forfatter har fylt ut ICMJE-skjemaet og oppgir ingen interessekonflikter.

\section{Litteratur}

1. Folkehelseinstituttet. Forekomst av diabetes: fakta og helsestatistikk om diabetes. Oslo: Folkehelseinstituttet, 2014. www.fhi.no/eway/ default.aspx?Main $6157=6263: 0: 25,58628$ MainContent $6263=6464: 0: 25,5863 \&$ List $6212=$ 6218:0:25,5872:1:0:0:0:0 (1.6.2014)

2. Claudi T, Ingskog W, Cooper JG et al. Kvaliteten på diabetesbehandlingen i allmennpraksis. Tidsskr Nor Legeforen 2008; 128: 2570-4.

3. Claudi T, Cooper J, Midtjell K et al. NSAMs handlingsprogram for diabetes i allmennpraksis. Oslo: Norsk selskap for allmennmedisin, Norges Diabetesforbund, Statens helsetilsyn, Statens institutt for folkehelse, Den norske legeforening, 2005.
4. Claudi T, Abrahamsen R, Andersen S et al. Diabetes: Forebygging, diagnostikk og behandling. Oslo: Helsedirektoratet, 2009

5. Krüger K. Elektroniske pasientjournaler bør være strukturerte. Tidsskr Nor Lægeforen 2007; 127: 2090-3.

6. Cooper JG, Claudi T, Jenum AK et al. Quality of care for patients with type 2 diabetes in primary care in Norway is improving: results of cross-sectional surveys of 33 general practices in 1995 and 2005. Diabetes Care 2009; 32: 81-3.

7. Worswick J, Wayne SC, Bennett R et al. Improving quality of care for persons with diabetes: an overview of systematic reviews - what does the evidence tell us? Syst Rev 2013; 2: 26.

8. Higgins JPT Altman DG Sterne JAC. Chapter 8 : Assessing risk of bias in included studies. I: Cochrane Handbook for Systematic Reviews of Interventions. Version 5.1.0. København: The Cochrane Collaboration, 2011. http://handbook.cochrane.org/ chapter $8 / 8$ assessing risk of bias in included studies.htm (30.10.2015).

9. Cochrane. Review Manager software (RevMan). RevMan 5.2. København: Cochrane Informatics \& Knowledge Management Department, 2012.

10. Brozek J, Oxman A, Schünemann H. GRADEpro. GDT: The Grading of Recommendations Assessment, Development and Evaluation (short GRADE) Working Group 2008. http://gradepro.org/ (30.10.2015).

11. Larun L, Kirkehei I, Rygh OM et al. Bruk av struktu rerte skjema i diabeteskontrollen i primærhelsetjenesten. Rapport. Oslo: Kunnskapssenteret i Folkehelsetjenesten, 2016

12. Larun L, Brurberg KG, Kirkehei I et al. Bruk av strukturerte skjema i diabeteskontrollen i primærhelsetjenesten - prosjektplan. Oslo: Nasjo nalt kunnskapssenter for helsetjenesten, 2014. www.kunnskapssenteret.no/prosjekter/ prosjektplan-for-bruk-av-strukturerte-skjema-idiabeteskontrollen-i-primaerhelsetjenesten (30.10.2015).

13. MacLean CD, Littenberg B, Gagnon M et al. The Vermont Diabetes Information System (VDIS): study design and subject recruitment for a cluster randomized trial of a decision support system in a regional sample of primary care practices. Clin Trials 2004; 1: 532-44

14. O'Connor PJ, Sperl-Hillen J, Johnson PE et al. Customized feedback to patients and providers failed to improve safety or quality of diabetes care a randomized trial. Diabetes Care 2009; 32 : $1158-63$.
15. O'Connor PJ, Sperl-Hillen JM, Rush WA et al. Impact of electronic health record clinical decision support on diabetes care: a randomized trial. Ann Fam Med 2011; 9: 12-21.

16. Cleveringa FG, Gorter KJ, van den Donk M et al. Combined task delegation, computerized decision support, and feedback improve cardiovascular risk for type 2 diabetic patients: a cluster randomized trial in primary care. Diabetes Care 2008; 31 : 2273-5.

17. Bebb C, Kendrick D, Coupland C et al. A cluster randomised controlled trial of the effect of a treatment algorithm for hypertension in patients with type 2 diabetes. Br J Gen Pract 2007; 57: 136-43.

18. Holbrook A, Thabane L, Keshavjee K et al. Individualized electronic decision support and reminders to improve diabetes care in the community: COMPETE II randomized trial. CMAJ 2009; 181 : $37-44$.

19. Olivarius NF, Beck-Nielsen $\mathrm{H}$, Andreasen AH et al. Randomised controlled trial of structured personal care of type 2 diabetes mellitus. BMJ 2001; 323: $970-5$

20. O'Connor PJ, Crain AL, Rush WA et al. Impact of an electronic medical record on diabetes quality of care. Ann Fam Med 2005; 3: 300-6.

21. Fretheim A, Flottorp S, Oxman AD. Effekt av tiltak for implementering av kliniske retningslinjer. Rapport. Oslo: Nasjonalt kunnskapssenter for helsetjenesten, 2015

22. Moja L, Kwag KH, Lytras T et al. Effectiveness of computerized decision support systems linked to electronic health records: a systematic review and meta-analysis. Am J Public Health 2014; 104 : e12-22.

23. Bright TJ, Wong A, Dhurjati R et al. Effect of clinical decision-support systems: a systematic review. Ann Intern Med 2012; 157: 29-43

24. Tricco AC, Ivers NM, Grimshaw JM et al. Effectiveness of quality improvement strategies on the management of diabetes: a systematic review and meta-analysis. Lancet 2012; 379: 2252-61.

25. Helsedirektoratet. Gjennomføre årskontroller og rutinekontroller ved diabetes 2015. https://helsedirektoratet.no/diabetes/ gjennomfore-arskontroller-og-rutinekontrollerved-diabetes (9.1.2015).

Mottatt 9.11. 2015, første revisjon innsendt 11.1. 2016, godkjent 8.2. 2016. Redaktør: Geir Wenberg Jacobsen. 